\title{
Introduction to JTD Cough Section
}

'Three things cannot be bidden: coughing, poverty and love'. This is originally Yiddish proverb, quoted in many texts and movies, which may well describe the hypersensitive nature of cough (1). The cough reflex is a primary airway defense mechanism against aspiration, but when dysregulated, it becomes a problem commonly presenting as irresistible bouts with hypersensitivity to various innocuous environmental or behavioral triggers (2). Importantly, cough is a common problem in general populations and is the single most common symptom for medical visits (3-5).

A major change during the recent decade is a paradigm shift in chronic cough. The recognition of cough hypersensitivity as the key pathophysiological mechanism underlying chronic cough has opened a new window of opportunity in the management of chronic cough $(6,7)$. Now we are getting more understanding of this disease condition, recently termed "cough hypersensitivity syndrome" by the European Respiratory Society Taskforce report (8). Thus, the Fournal of Thoracic Disease (FTD) initiated a dedicated section for Cough in 2016, which was led by Prof. Peter Dicpinigaitis (9), and now aims to continue its vision to promote our understanding and refine our clinical strategy for cough. The Cough Section will feature original studies as well as state-of-the-art reviews, opinion papers, and selected letters. We hope this section could serve as a good field for scientific communication and enhancing creativity for cough. We invite clinicians and scientists to submit their works to the Cough Section of the $7 T D$.

\section{Acknowledgments}

None.

\section{Footnote}

Conflicts of Interest: The author has no conflicts of interest to declare.

Ethical Statement: The author is accountable for all aspects of the work ensuring that questions related to the accuracy or integrity of all parts of the work are appropriately investigated and resolved.

\section{References}

1. Song WJ, Morice AH. Cough Hypersensitivity Syndrome: A Few More Steps Forward. Allergy Asthma Immunol Res 2017;9:394-402.

2. Chung KF, McGarvey L, Mazzone SB. Chronic cough as a neuropathic disorder. Lancet Respir Med 2013;1:414-22.

3. Dicpinigaitis PV. Cough: an unmet clinical need. Br J Pharmacol 2011;163:116-24.

4. Lai K, Chen R, Lin J et al. A prospective, multicenter survey on causes of chronic cough in China. Chest 2013;143:613-20.

5. Song WJ, Chang YS, Faruqi S, et al. The global epidemiology of chronic cough in adults: a systematic review and meta-analysis. Eur Respir J 2015;45:1479-81.

6. Morice AH, Millqvist E, Bieksiene K, et al. ERS guidelines on the diagnosis and treatment of chronic cough in adults and children. Eur Respir J 2019. [Epub ahead of print].

7. Abdulqawi R, Dockry R, Holt K, et al. P2X3 receptor antagonist (AF-219) in refractory chronic cough: a randomised, doubleblind, placebo-controlled phase 2 study. Lancet 2015;385:1198-205.

8. Morice AH, Millqvist E, Belvisi MG, et al. Expert opinion on the cough hypersensitivity syndrome in respiratory medicine. Eur Respir J 2014;44:1132-48.

9. Dicpinigaitis P. Introduction to JTD Cough Section. J Thorac Dis 2016;8:631. 


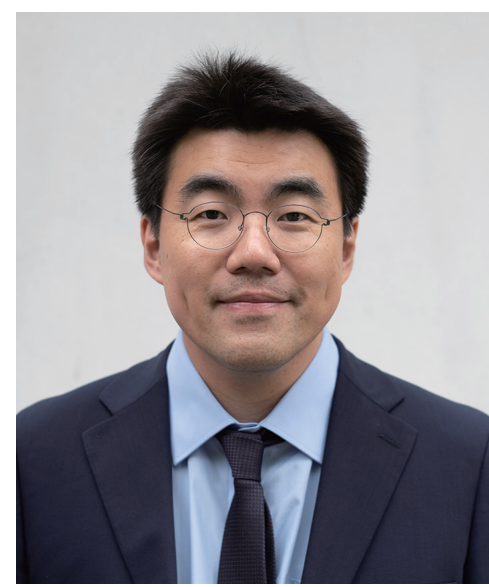

Woo-Jung Song

Woo-Jung Song, MD, PhD Associate Professor, Department of Allergy and Clinical Immunology, Airway Sensation and Cough Research Laboratory, Asan Medical Center, University of Ulsan College of Medicine, Seoul, Korea. Cough Section Director, Fournal of Thoracic Disease (Email: swj0126@amc.seoul.kr) doi: $10.21037 /$ jtd.2019.12.22

View this article at: http://dx.doi.org/10.21037/jtd.2019.12.22

Cite this article as: Song WJ. Introduction to $7 T D$ Cough Section. J Thorac Dis 2019;11(12):5601-5602. doi: 10.21037/ jtd.2019.12.22 